Tsaqofiya : Jurnal Pendidikan Bahasa dan Sastra Arab

Vol. 4 No. 1 Januari 2022, 28-44

P-ISSN : 2685-7022, E-ISSN : 2685-7103

DOI: $10.21154 /$ tsaqofiya.v4i1.88

\title{
Aspek Kecemasan (Anxitas) dalam Puisi Al-Kulira Karya Nazek Al-Malaika (Kajian Psikologi Sastra)
}

\author{
Murisatin Nikmah, Mochammad Faizun \\ UIN Sayyid Ali Rahmatullah Tulungagung \\ Murisatin14@gmail.com
}

\begin{abstract}
The purpose of this study to find out the anxiety aspect in literary works. The main data source of this study is Nazek Al-Malaika's Al-Kulira poem, one of the poems based on the emotional effects of the cholera outbreak in Egypt in 1947. This study uses qualitative descriptive method by describing and analyzing the form and meaning contained in the poem Al-Kulira by nazek Al-Malaika then identify which sentences or lines of poetry correspond to the aspect of anxiety and relate to the theory of psychoanalytic personality sigmund Freud. The result of this study is Freud distinguished three structures or agents in human psychic life, "the conscious", "the preconscious", and the "unconscious." In the psychic unconscious there is a personality dynamic in the form of anxiety consisting of objective anxiety, neurotic anxiety, and morality anxiety.
\end{abstract}

Keywords: Al-Kulira, Nazek Al-Malaika, Anxiety

\section{Abstrak}

Penelitian ini bertujuan untuk mengetahui aspek kecemasan (Anxitas) dalam karya sastra. Sumber data utama penelitian ini adalah puisi Al-Kulira karya Nazek AlMalaika, salah satu puisi yang didasarkan pada efek emosional dari wabah kolera di Mesir pada tahun 1947. Penelitian ini menggunakan metode deskriptif kualitatif, yakni dengan mendeskripsikan dan menganalisis bentuk dan makna yang terkandung di dalam puisi Al-Kulira karya nazek Al-Malaika untuk kemudian diidentifikasi mana kalimat atau baris puisi yang sesuai dengan aspek kecemasan (Anxitas) dan berhubungan dengan teori kepribadian psikoanalisis Sigmund Freud. Hasil dari penelitian ini adalah Freud membedakan tiga struktur atau agen dalam kehidupan psikis manusia terdiri dari, "yang sadar", "prasadar", dan "tak sadar." Dalam psikis tak sadar terdapat dinamika kepribadian berupa kecemasan (Anxitas) yang terdiri dari kecemasan (Anxitas) objektif, kecemasan (Anxitas) neurotik, dan kecemasan (Anxitas) moral.

Kata Kunci: Al-Kulira, Nazek Al-Malaika, Kecemasan 


\section{PENDAHULUAN}

Karya sastra tidak pernah lepas dari pengarangnya. Adanya sebuah karya pasti ada latar belakangnya, mengenai bagaimana kondisi kejiwaan pengarang saat itu dan apa latar belakang yang memengaruhi pengarang menciptakan karya sastra. Psikologi pengarang merupakan salah satu wilayah psikologi kesenian yang membahas aspek kejiwaan pengarang sebagai suatu tipe maupun sebagai seorang pribadi, yang menjadi fokus adalah aspek kejiwaan pengarang yang memiliki hubungan dengan proses lahirnya karya sastra. ${ }^{1}$ Seperti yang telah diketahui bahwa psikologi kepribadian merupakan psikologi yang mempelajari kepribadian manusia dan apa yang memengaruhi tingkah lakunya. Kaitannya dengan pengamatan dan perkembangan serta bagaimana seorang individu menyesuaikan dengan lingkungannya.

Karya-karya sastra seperti halnya puisi dapat memberikan informasi berharga mengenai tingkah laku manusia. Fungsi psikologi kepribadian itu sendiri yang pertama sebagai fungsi deskriptif (menguraikan) tingkah laku dan kejadian yang dialami individu secara sistematis. Yang kedua sebagai fungsi prediktif yaitu mampu meramalkan tingkah laku atau kejadian yang belum muncul dalam diri individu. ${ }^{2}$ Dalam psikologi sendiri terdapat tiga aliran pemikiran (revolusi yang memengaruhi pemikiran personologis modern). Salah satunya psikoanalisis yang menghadirkan manusia sebagai bentuk dari naluri-naluri juga konflik-konflik struktur kepribadian. ${ }^{3}$ Teori psikoanalisis itu berhubungan dengan perkembangan mental manusia. Merupakan bagian dari ilmu psikologi dan telah memberikan kontribusi besar untuk psikologi manusia selama ini. ${ }^{4}$ Sebagian besar karya sastra dipengaruhi oleh psikologi pengarang itu sendiri. Penyair adalah pencipta puisi, sedangkan puisinya adalah perwujudan dari persepsi hidupnya. ${ }^{5}$

\footnotetext{
1 Wiyatmi, Psikologi Sastra, (Yogyakarta: Kanwa Publisher, 2011) h. 30

2 Albertine Minderop, Psikologi Sastra, (Jakarta: Yayasan Pustaka Obor Indonesia Anggota IKAPI DKI Jakarta, 2010) h. 8

${ }^{3}$ Ibid., h. 9

${ }^{4}$ Ali Nur Yasin and Darisy Syafaah, "Struktur Kepribadian Tokoh Iryân Dalam Novel Al-Rajulu Al-Lazî Âmana Karya Najib Al-Kailani (Analisis Psikologi Sigmund Freud)," Tsaqofiya: Jurnal Pendidikan Bahasa Dan Sastra Arab 3, no. 1 (2021): 61-75.

${ }^{5}$ Khoiriyatul Fajriyah, dkk, Juni 2017, Kajian Psikologi Sastra, (FIB KALTIM : volume 3, nomor 1) h. 5
} 
Penelitian ini akan membahas puisi yang berjudul Al-Kulira karya Nazek AlMalaika. Puisi ini merupakan puisi Arab modern pertama yang bersajak bebas. ${ }^{6}$ Dikatakan bebas karena dari susunan larik, isi, dan gaya bahasa serta pemilihan katanya lebih bebas dari puisi Arab klasik. Puisi Al-Kulira ini diterbitkan pada tahun 1367 H (1947 M). ${ }^{7}$ Puisi ini menceritakan tentang kejadian pada tahun 1947 di mana negara Mesir terserang wabah epidemi kolera. Beritanya selalu dikabarkan di radio tentang beratus korban jiwa yang meninggal setiap harinya. Bagaimana kondisi masyarakat saat itu, mereka kehilangan keluarganya. Setiap hari hanya ada tangisan dan kesakitan, seorang anak yang ditinggalkan orang tuanya, serta penderitaan masyarakat yang terjangkit penyakit kolera. Kolera merupakan penyakit infeksi saluran usus yang bersifat akut yang disebabkan oleh bakteri vibrio cholera dan pada saat itu belum ada obat yang dapat mengatasinya. Mereka tidak memiliki harapan untuk sembuh dan hanya bisa pasrah tentang apa yang akan terjadi.

Nazek Al-Malaika ini merupakan penyair dan kritikus Irak, juga seorang peneliti wanita Arab. Ia juga pendukung utama gerakan ayat bebas pada akhir 1940an bersama Badr Shakir al-Sayyab. Puisi-puisinya memiliki ciri khas kesederhanaan bahasa, kefasihan dan lain sebagainya. Puisi karya Nazek Al-Malaika didominasi oleh lirik yang elegi. Elegi adalah puisi lirik yang berisi tentang duka dan ratapan sebuah kematian dari seseorang (biasanya orang yang dicintai atau dikagumi oleh penyair) atau juga sebuah kematian dari beberapa orang. Banyak puisi Nazek yang bertema tentang kematian, perasaan sedih yang mendalam, rasa kecewa, putus asa, melankolis, dan ratapan. ${ }^{8}$

Salah satunya adalah Al-Kulira, namun tidak hanya "Al-Kulira" saja tetapi masih banyak karya-karya Nazek yang lainnya seperti, shazaya wa ramaad 1949, qaraarat al-mawja 1957. Syajaratu al-qamar 1968, wa yugayyiru al-waanahu al-bahr 1970. Bahkan karya-karyanya telah diterjemahkan dalam berbagai bahasa seperti Inggris, Perancis, dan Spanyol. Karya sastranya yang mengungkapkan rasa depresi yang dialaminya itu banyak mendapatkan perhatian dan juga digunakan sebagai bahan studi akademik dan seminar di berbagai universitas. ${ }^{9}$ Banyak puisi Nazek yang

${ }^{6}$ Nurfitri \& Fauzan Muslim, Tema Kesedihan dalam Puisi Al-Kuuliiraa Karya Nazek Al-Malaikah, (FIB, 2014), h. 20-23

7 Ibid., h. 20-23

8 Ibid., h. 2

9 Ibid., h. 2 
didasarkan pada tema kematian, kesedihan, kekecewaan, dan kesedihan yang mendalam. Ia juga lebih banyak menuliskan tentang dirinya sendiri karena kondisi psikologinya. Nazek berusaha mengungkapkan perasaan cemas, depresi dan perasaan sedihnya kedalam puisinya. Beberapa sumber yang penulis dapat juga menyebutkan bahwa Nazek sempat menderita depresi berat setelah ibunya meninggal, itu awal puisi sedihnya dimulai. Pada tahun 1953 setelah ibunya meninggal, ia menangis siang dan malam hingga kesedihannya menjadi penyakit dalam dirinya. Oleh karena itu tak peduli apa yang ia tulis terlepas dari kondisi yang terjadi selalu ada perasaan sedih di dalamnya karena dipengaruhi oleh psikologinya. Sehingga karya atau puisi yang dihasilkan kebanyakan bersifat melankolis. ${ }^{10}$

Untuk mengetahui aspek kecemasan apa saja yang ada dalam puisi Al-Kulira karya Nazek Al-Malaika penulis menggunakan teori kepribadian psikoanalisis Sigmund Freud. Psikoanalisis ditemukan sekitar tahun 1890-an, dan dimulai sekitar tahun 1900-an oleh Sigmund Freud. Ilmu ini merupakan bagian dari psikologi yang memberikan kontribusi besar dan dibuat untuk psikologi manusia selama ini. Psikoanalisis memang bagian dari psikologi, namun yang membedakan adalah jika psikologi secara umum membahas mengenai kejiwaan maka psikoanalisis ini membahas mengenai fungsi perkembangan mental manusia.

Menurut Freud alam bawah sadar itu penting untuk dibahas dalam psikologi sastra, karena sebuah karya seni sejatinya tidak bisa terlepas dari penciptanya. ${ }^{11}$ Psikologi adalah ilmu yang mempelajari tentang tingkah laku manusia dan hewan yang diterapkan pada permasalahan manusia. ${ }^{12}$ Yang memfokuskan pada perilaku individual meliputi perilaku secara luas. ${ }^{13}$ Dalam hal ini mental internal dapat dipelajari, karena mereka muncul dari perilaku manusia itu sendiri. Melalui perilaku kita bahkan bisa mempelajari dan memahami proses mental yang tersembunyi maupun tidak dari diri kita. ${ }^{14}$ Psikologi dalam hal ini (psikoanalisis) bisa memengaruhi psikologi siapa saja, termasuk tokoh sastra itu sendiri. Psikoanalisis juga sering menstimulasi "kondisi mental" penciptanya sehingga munculah ide teks sastra. Seorang penyair terkadang menjadi "pelamun" yang lepas dari realitas

10 Ibid., h. 2

11 Suwardi Endraswara, Metodologi Penelitian Sastra, (Yogyakarta: CAPS (Center for Academic Publishing Service), 2013) h. 103

12 Intaglia Harsanti, dkk, Psikologi Umum 1, (Universitas Gunadarma, 2013) h. 2

13 Ibid., h. 4

14 Ibid., h. 5 
kehidupan. Karena baginya kreativitas adalah pelarian (escapism), yang artinya pergolakan jiwa manusia tidak hanya melibatkan kesinambungan kesadaran bagi orang yang bersangkutan tetapi juga melibatkan gejolak yang tidak disadari pada orang tersebut.

Pada periode pertama Freud membedakan tiga struktur atau agen dalam kehidupan psikis manusia yaitu, "yang sadar", "prasadar", dan "tak sadar."15 Sadar (consious) adalah bagian dari kehidupan mental atau lapisan jiwa individu. Dimana kehidupan mental ini berupa (pikiran, persepsi, perasaan dan ingatan) sepenuhnya disadari (fully aware) kita menyadari apa yang sedang kita kerjakan. Prasadar (preconscious) adalah kehidupan mental di alam bawah sadar, sebagai tempat berlindung dari ingatan yang tidak dapat diungkapkan dengan cepat tetapi dengan upaya tertentu sesuatu dapat ditarik atau diingat kembali. Dalam hal ini maksudnya sesuatu yang pernah kita lakukan tersimpan pada memory prasadar, jika kita mengingatnya kembali maka kita akan sadar bahwa kita pernah melakukannya. Tak sadar (Unconscious) adalah bagian terdalam dari struktur kesadaran dan merupakan bagian terpenting dari jiwa manusia. Area ini adalah gudang dari insting-insting (naluri) yang di-refresh atau pengalaman yang tidak menyenangkan (emotional pain). Meskipun individu sama sekali tidak menyadari keberadaan insting ini, namun insting ini adalah penentu utama perilaku individu. Di sinilah puncaknya, di mana sesuatu yang ingin kita lupakan dan kubur dalam-dalam justru sangat memengaruhi jiwa dan mental seseorang. ${ }^{16}$ Di sinilah pribadi pengarang akan memengaruhi ruh karyanya.

Insting adalah kekuatan pendorong atau pemotivasi kepribadian, kekuatan biologis yang melepaskan energi mental. Insting yang mungkin dimiliki manusia dibedakan menjadi dua kategori umum yaitu insting hidup dan insting mati. Insting hidup meliputi rasa lapar, rasa haus, dan aktivitas seksual yang berhubungan dengan keberlangsungan hidupnya dalam melestarikam keturunan. Energi ini menjadi tempat insting memanifestasikan dirinya yang disebut libido (nafsu birahi yang bersifat naluri). Sedangkan insting mati diarahkan dari dalam diri seperti terdapat

15 Yasin and Syafaah, "Struktur Kepribadian Tokoh Iryân Dalam Novel Al-Rajulu Al-Lazî Âmana Karya Najib Al-Kailani (Analisis Psikologi Sigmund Freud)."

${ }^{16}$ Fajriyah Khoiriyatul, dkk. Juni 2017. Kajian Psikologi Sastra. FIB KALTIM: volume 3, nomor 1. h. 5 
siksaan atau penderitaan, bunuh diri, kebencian dan agresi (sesuatu yang mengecewakan).

Bagi para psikoanalisis, kepribadian merupakan pengutamaan alam bawah sadar "tak sadar" (unconscious) yang berada di luar sadar, dan membuat struktur berpikir diwarnai oleh emosi. Mereka berasumsi bahwa perilaku seseorang tidak hanya dilihat dari sekedar wajahnya saja tetapi untuk memahami secara mendalam kepribadian seseorang harus diamati dari gelagat simbolis dan pikiran yang mendalam dari orang tersebut. Mereka mempercayai bahwa pengalaman masa kecil individu telah membentuk kepribadiannya. Bahkan Freud telah melakukan pengamatan secara mendalam bahwasannya memang benar pengalaman masa kecil seseorang dapat memengaruhi kepribadiannya hingga dewasa. ${ }^{17}$ Menurut Freud kecemasan merupakan libido yang mengendap dan berasal dari trauma masa lahir. ${ }^{18}$ Dalam dinamika kepribadian kecemasan (Anxitas) merupakan keadaan atau situasi apapun yang mengganggu dan mengancam kenyamanan organisme. Mulai dari berbagai konflik, frustasi, dan apapun yang bisa menghambat tujuan dari seseorang (bentuk ancaman fisik, psikis dan berbagai tekanan, merasa khawatir, takut, dan tidak bahagia). Kecemasan (Anxitas) terdiri dari kecemasan (Anxitas) objektif atau realitas dimana seseorang merasa takut ketika merasakan bahaya dalam lingkungan atau sesuatu yang dapat mengancamnya di dunia nyata. Kecemasan ini menuntun seseorang berperilaku dalam menghadapi bahaya. Bahkan tidak jarang orang yang mengalami kecemasan objektif ini menjadi ekstrim. Seperti halnya seseorang menjadi sangat takut untuk keluar rumah karena karena merasa akan mengalami bahaya jika dirinya keluar.

Kemudian kecemasan (Anxitas) neurotik dimana terdapat konflik antara alam bawah sadar dan diri individu tersebut, sebab individu tersebut tidak menyadari apa alasannya mengalami rasa cemas. Freud membaginya menjadi tiga bagian yang berbeda diantaranya: kecemasan neurotik karena faktor dalam dan luar yang menakutkan, kecemasan neurotik terkait objek tertentu (fobia), dan kecemasan neurotik yang tidak berhubungan dengan faktor-faktor berbahaya dari dalam maupun luar. Individu yang tidak menyadari apa alasannya mengalami rasa cemas ini

${ }^{17}$ Albertine Minderop, Psikologi Sastra, h. 9-11

18 Andri, Yeny Dewi P, Teori Kecemasan Berdasarkan Psikoanalisis Klasik dan Berbagai Mekanisme Pertahanan terhadap Kecemasan, (Departemen Psikiatri Fakultas Kedokteran UI : Maj Kedokteran Indonesia, Vol. 57, nomor 7, Juli 2007) h. 1 
terkena gangguan panik dan masuk kelompok ketiga. Penderita tidak mampu menjelaskan bahaya yang mampu dikenali. Gejala fisiologis yang muncul dalam serangan panik seperti palpitasi, dispnea, adanya rasa takut mati serta kecemasan akan terulangnya kejadian tersebut. ${ }^{19}$

Serta yang terakhir kecemasan (Anxitas) moral dimana terdapat ketakutan dan kecemasan pada suara hati individu itu sendiri yang diakibatkan dari pertentangan antara kata hati dan kehidupan sosialnya (yang ada di dalam masyarakatnya). ${ }^{20}$ Apapun tipenya, kecemasan merupakan suatu tanda peringatan terhadap seseorang atau individu itu sendiri. Hal ini menyebabkan tekanan dan dorongan pada suatu individu seperti perasaan cemas, takut, khawatir, dan tidak bahagia tersebut. ${ }^{21}$

Freud mengatakan, "orang yang memiliki mata untuk melihat, telinga untuk mendengar meyakini bahwa tak ada makhluk bernyawa yang dapat menyimpan rahasia. Karena jika bibir terdiam, dia akan berbicara dengan jari-jemarinya, mengkhianati emosi yang keluar dari dalam tubuhnya melalui setiap pori-porinya. Sehingga membawa bagian-bagian pikiran yang terpendam ke kesadaran adalah sesuatu yang sangat mungkin dilakukan." Dalam hal ini ketika Nazek mulai cemas, gelisah, ketakutan dan mengalami tekanan dengan adanya wabah kolera yang menyerang Mesir yang telah membunuh ratusan orang setiap harinya ia yang tak tahu harus berbuat apa lantas membuat puisi Al-Kulira ini untuk mengekspresikan tragedi tersebut. Sebab tekanan dari alam bawah sadarnyalah yang mendorongnya untuk melakukan semua itu. Pikirannya gelisah, namun jari jemarinya mampu menuliskan puisi tentang peristiwa tersebut.

Penelitian mengenai objek puisi Al-Kulira karya Nazek Al-Malaika sudah banyak dilakukan oleh beberapa peneliti diantaranya yang dilakukan oleh Achmad Atho'illah dari the muallaqat forum jogyakarta yang membahas puisi Al-Kulira karya Nazek Al-Malaika mengenai biografi dan pemikirannya tentang puisi bebas dalam segi ilmu arudh. ${ }^{22}$ Kemudian penelitian yang dilakukan oleh Nurfitri dan Fauzan Muslim dari program studi sastra Arab FIB Universitas Indonesia membicarakan mengenai tema kesedihan di dalam puisi Al-Kulira karya Nazek Al-Malaika

\footnotetext{
19 Ibid., h. 3

${ }^{20}$ Albertine Minderop, Psikologi Sastra, h. 28

21 Andri, Yeny Dewi P, Teori Kecemasan Berdasarkan Psikoanalisis Klasik dan Berbagai Mekanisme Pertahanan terhadap Kecemasan, h. 1

${ }^{22}$ Asabiyyat, Juni 2009, (vol.8, No.1,), h. 6-7
} 
menggunakan teori analisis struktural. ${ }^{23}$ Sedangkan penelitian yang dilakukan oleh Noor Nailarrochim dari program studi Bahasa dan Sastra Arab Universitas Islam Negeri Sunan Kalijaga Yogyakarta membahas puisi Al-Kulira karya Nazek Al-Malaika menggunakan teori semiotika Riffaterre. ${ }^{24}$

Berdasarkan tinjauan yang didapat, penelitian dengan judul "Aspek Kecemasan dalam Puisi Al-Kulira Karya Nazek Al-Malaika (Kajian Psikologi Sastra)" belum pernah dilakukan sama sekali. Terdapat beberapa penelitian dengan objek yang sama tetapi teori yang digunakan tidak sama. Peneliti meneliti puisi Al-Kulira karya Nazek Al-Malaika menggunakan teori kepribadian psikoanalisis Sigmund Freud, dikarenakan belum ada yang membahasnya. Padahal menurut penulis ini adalah ilmu yang penting dan merupakan acuan bagi seorang sastrawan ketika nantinya ingin melakukan penelitian di bidang psikologi sastra.

Adapun alasan memilih penelitian ini untuk menjelaskan apa saja kecemasan (Anxitas) yang ada dalam puisi Al-kulira. Serta kaitannya dengan psikologi pengarang itu sendiri. Seperti halnya dalam penciptaan puisi Al-Kulira ini, di mana pengarangnya yakni Nazek Al-Malaika mengalami kesedihan dan kegelisahan jiwa akibat wabah kolera yang menyerang Mesir. Ia lantas membuat karya sastra berupa puisi Al-Kulira tersebut untuk mengekspresikan perasaannya pada saat itu. Sehingga ketika membaca puisi Al-Kulira, kita seolah bisa merasakan apa yang yang dialami oleh Nazek dan masyarakat Mesir. Ini membuktikan bahwa psikologi kepribadian sangat berperan secara intern terhadap hasil karya sastra itu sendiri. Oleh sebab itu aspek kecemasan (psikologi sastra) dalam puisi Al-Kulira karya Nazek Al-Malaika sangat penting untuk diteliti dan dipelajari dalam dunia keilmuan khusunya bidang psikologi sastra.

\section{METODE}

Metode yang digunakan dalam penelitian ini adalah metode deskriptif kualitatif yakni mendeskripsikan bentuk dan makna yang terkandung di dalam puisi Al-Kulira karya Nazek Al-Malaika. Penelitiannya berorientasi pada fenomena atau gejala yang bersifat alami (riset) dengan menguraikan data yang dianalisis dalam

${ }^{23}$ Nurfitri., h. 4

24 Noor Nailarrochim, Puisi Al-Kulira Karya Nazik Al-Mala'ikah (Studi Analisis Semiotika Michael Riffaterre), ('Ajamiy: volume 9 no 2, 2020) h. 3 
bentuk kata-kata atau kalimat. ${ }^{25}$ Jenis penelitiannya termasuk kedalam kepustakaan (library research) dan datanya diperoleh dari sumber yang jelas dengan referensi berupa buku, jurnal, skripsi yang relevan dan berhubungan dengan penelitian ini.

Fokus penelitian ini tentang kecemasan apa saja yang ada di dalam puisi AlKulira. Adapun data pada penelitian ini berupa baris puisi yang termasuk kedalam aspek kecemasan dan macam-macam kecemasan yang ada dalam puisi Al-Kulira. Sedangkan sumber data utamanya tentu saja baris dalam puisi Al-Kulira karya Nazek Al-Malaika dengan menganalisis data dan membaca puisi serta maksudnya secara berulang-ulang, teliti kemudian diidentifikasi ${ }^{26}$ mana baris puisi yang mengandung aspek kecemasan dalam puisi tersebut.

Untuk menganalisis puisi Al-Kulira menggunakan teori deskriptif analisis. ${ }^{27}$ Data yang telah diperoleh dianalisis melalui beberapa tahapan, yang pertama penulis membaca keseluruhan puisi Al-Kulira dengan teliti juga komprehensif. Kemudian yang kedua penulis mengidentifikasi sekaligus menentukan baris puisi mana yang mengandung kategori kepribadian dan masuk kedalam aspek kecemasan Sigmund Freud. Selanjutnya barulah menyimpulkan aspek kecemasan apa saja yang ada dalam puisi Al-Kulira tersebut.

\section{PEMBAHASAN}

Puisi Al-Kulira terdiri dari 53 baris, dan peneliti telah berhasil mengumpulkan serta mengklasifikasikan mana saja baris puisi yang masuk kedalam aspek kecemasan dan macam-macamnya. Kecemasan (Anxitas) objektif ada enam bentuk, kecemasan (Anxitas) neurotik ada empat bentuk dan kecemasan (Anxitas) moral ada dua bentuk. Namun lebih di dominasi oleh Kecemasan (Anxitas) objektif.

\section{Baris 1-4}

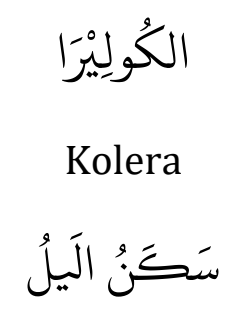

\footnotetext{
${ }^{25}$ Puji Santosa, Metodologi Penelitian Sastra Paradigma, Proposal, Pelaporan, Dan Penerapan, (Yogyakarta: Azzagrafika, 2015) h. 19

${ }^{26}$ Nazia Maharani Umaya, Harjito, Penelitian Pembelajaran Sastra, (Semarang: Universitas PGRI Semarang Press, 2017) h. 88

27 Nyoman Kuta Ratna, Teori, Metode, Teknik Penelitian Sastra, (Yogyakarta: Pustaka Pelajara, 2015) h. 47-48
} 


\section{Malam Tenang \\ أصغن إللَ وَقْقِ صَدَى الأنَّاتُ}

Dengarlah tanda rintihan yang menggema

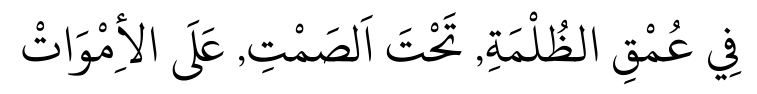

Di kegelapan yang kelam, dalam keheningan, terdapat kematian

Pada keempat baris puisi tersebut masuk kedalam kecemasan (Anxitas) neurotik berupa fobia terhadap kematian. Ini juga ada kaitannya dengan psikologi Nazek yang sejak kecil sudah ditinggal ibunya dan orang-orang tersayangnya yang akhirnya membuat psikisnya terganggu karena takut pada kematian.

\section{Baris 5-8}

$$
\text { صَرَخَاتُ تَعْلُو, تَضْطِرِبُ }
$$

Jeritan meninggi, menyakitkan

$$
\text { حَزَنْ يَتَدَفَقُ, يَتْتَهُبُ }
$$

Sedih mengalir, meradang

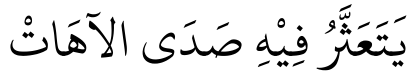

Di sana ada gejolak rintih yang bersautan

$$
\text { فَي كِلِ فُوًَادٍ غُليانْ }
$$

Di setiap hati yang mendidih

Pada keempat baris puisi tersebut masuk kedalam kecemasan (Anxitas) objektif. Karena pada saat itu penyakit kolera yang menyerang sistem pencernaan masyarakat Mesir belum ada obatnya. Sehingga mereka benar-benar merasakan sakit yang teramat parah dan akhirnya meninggal.

\section{Baris 9-11}

$$
\text { فِي الكُوْْ السَاكِن أَخْزَانُ }
$$

Dalam gubuk sunyi bersemayam kesedihan

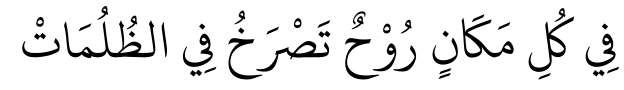

Di setiap kegelapan ada ruh yang menjerit

$$
\text { فِي كُلّ مَكَانِ يَبْكِي صَوُتْ }
$$

Di mana-mana terdengar suara tangisan

Pada ketiga baris puisi tersebut masuk kedalam kecemasan (Anxitas) neurotik 
berupa fobia (peristiwa yang tidak mengenakan pada masa lalu atau sedari kecil yang tidak ingin terulang kembali). Ditandai dengan kata-kata dalam puisi tersebut berupa kegelapan, sunyi, ruh yang menandakan peristiwa menakutkan dan siapapun yang mendengarnya merasa cemas akan keadaan tersebut.

\section{Baris 12-13}

$$
\text { هَذَا مَا قَدْ مَزَّ قَهُهُ المَوَتْ }
$$

Inilah robekan kematian

$$
\text { الموَتُ الموَتُ الموَتْ }
$$

Kematian kematian kematian

Kedua baris puisi tersebut masuk kedalam kecemasan (Anxitas) neurotik berupa fobia sebagai penguatan dari baris sebelumnya, yaitu kematian. Siapapun akan merasa cemas dan takut mendengar kata-kata mati.

\section{Baris 14-18}

$$
\text { يَا حُزْنَ النِيلِ الصَارَخَ مِمَا فَعَلَ الموَتُ }
$$

Duhai duka Nil menjerit atas ulah kematian

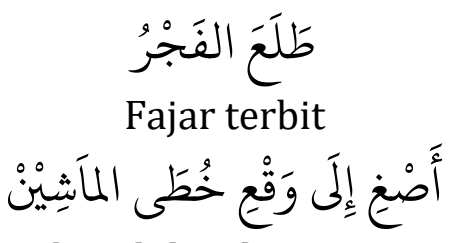

Lihatlah jejak terlukis dari para pejalan kaki

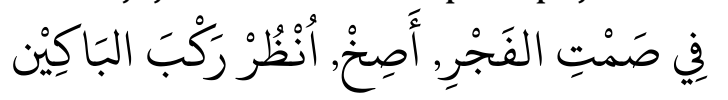

Dalam heningnya fajar, perhatikan, lihatlah kafilah para penduka

$$
\text { عَشَرَةُ أََْوَاتِاتِ, عِشْروْْنَا }
$$

Sepuluh kematian, berubah dua puluh

Pada kelima baris puisi tersebut masuk kedalam kecemasan (Anxitas) objektif. Karena wabah kolera benar-benar nyata dan bisa menyerang siapapun tanpa terkecuali. Tidak memandang gelar atau jabatan apapun, semuanya pasti akan mati.

\section{Baris 19-22}

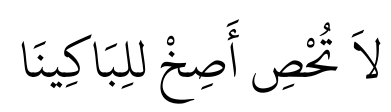

Jangan hitung orang yang mati, tapi perhatikan orang yang menangis 


$$
\text { إسْمَعْ صَوتَ الطِفْلِ الِمنِكِيْن }
$$

Dengarlah suara tangisan anak yang malang

$$
\text { مَوْنَّى, مَوْنََّ, ضَاعَ العَدَدُ }
$$

Mayat, mayat, bilangan yang telah hilang

$$
\text { مَوْنَى, مَوْنَ, لَمْ يَبْقَ غَدُ }
$$

Mayat, mayat, tak menyisakan hari esok

Pada keempat baris puisi tersebut masuk kedalam kecemasan (Anxitas) objektif. Menjelaskan bahwa kematian mampu menghadirkan perasaan takut dan cemas pada diri anak-anak. Mereka harus menyaksikan keluarganya bahkan orang tuanya meninggal akibat wabah kolera.

\section{Baris 22-26}

$$
\text { فَي كُلِّ مَكَانٍ جَسَدُ يَنْدُبُه مَحْزُونْ }
$$

Di setiap tempat ada mayat yang diratapi kesedihan

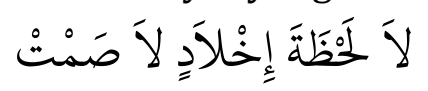

Tidak ada jeda yang menghampiri keheningan

$$
\text { هَذَا مَا فَعَلَتْ كَفُّ المَوَتْ }
$$

Inilah yang dilakukan tangan kematian

$$
\text { المَوتُ الموَتُ المَوَتْ }
$$

Kematian, kematian, kematian

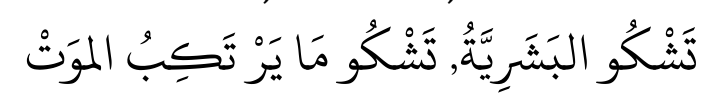

Manusia mengeluh, mengeluh atas apa yang dilakukan kematian

Pada kelima baris puisi tersebut masuk kedalam kecemasan (Anxitas) objektif. Menjelaskan bagaimana wabah kolera sangat berbahaya, menyebar keseluruh tempat dan penderitanya pasti akan mati.

\section{Baris 27-29}

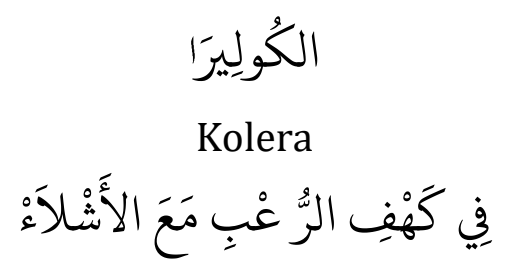

Dalam gua yang menakutkan dan kelumpuhan

$$
\text { فِي صَمْتِ الأَبَدِ القَاسِي حَيْثُ المَوَتُ دَوَاءْ }
$$


Pada ketiga baris puisi tersebut masuk kedalam kecemasan (Anxitas) moral. Karena tidak ada yang bisa dilakukan untuk menyembuhkan para korban. Bahkan pengarang maupun petugas medis saat itu hanya bisa pasrah. Makanya dalam baris tersebut Nazek seolah menuliskan pesan tersirat bahwa "seolah mati yang menjadi obatnya."

\section{Baris 30-33}

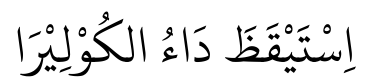

Kolera telah bangkit

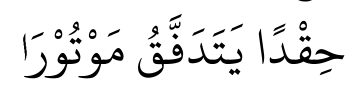

Dengki yang mengalir deras

$$
\text { هَبَطَ الوَادِي المِِحَ الوَضَّاءْ }
$$

Turun ke oase kebahagiaan murni

$$
\text { يَصْرَخْ مُضْطَرَبَا مَجْنوْنَا }
$$

Menjerit kebingungan, menggila

Pada keempat baris puisi tersebut masuk kedalam kecemasan (Anxitas) neurotik berupa kepanikan. Menjelaskan bagaimana secara tiba-tiba wabah kolera datang menghancurkan kebahagiaan masyarakat Mesir. Seolah wabah ini ingin balas dendam tanpa ampun dengan menyerang masyarakatnya tanpa tersisa, yang diisyaratkan dalam baris tersebut "dengki mengalir deras."

\section{Baris 34-38}

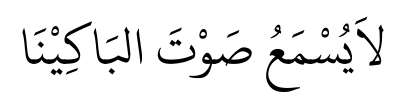

Ia tak mendengar suara tangisan

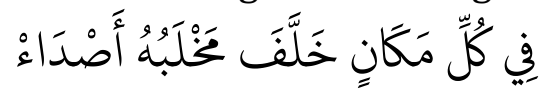

Di balik pegangan di setiap tempat yang terus menggema

$$
\text { فِي كُوْت الفَلاََّحَةِ فِي البَيتت }
$$

Di gubuk petani di dalam rumah

$$
\text { لا شَيَءَ سِوَى صَرَخَاتُ المَوَتْ }
$$

Tidak ada apa-apa selain jeritan kematian

$$
\text { الموَتُ الموَتُ الموَتْ }
$$

Kematian kematian kematian 
Pada kelima baris puisi tersebut masuk kedalam kecemasan (Anxitas) objektif berupa kepanikan dan ketakutan yang terjadi secara nyata. Menjelaskan bahwa entah di dalam rumah atau di luar rumah hanya ada tangisan dan kematian.

\section{Baris 39-45}

$$
\text { فِي شَخْصِ الكُوِلِيْرَا القَابِي يَنْتَقِمُ الموَتْ }
$$

Dalam tubuh penderita Kolera terdapat kematian, menyiksa

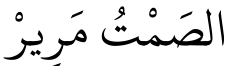

Keheningan, pahit

$$
\text { لا شَيَءَ سِوَى رَجْعَ التَكْبِيْ }
$$

Tak ada sesuatupun kecuali suara takbir

$$
\text { حَتَّى حَفَّارُ القَبْرِ ثَوَى لَم يَبْقَ نَصِيْ }
$$

Hingga penggali kubur pun mati tidak ada yang menolongnya

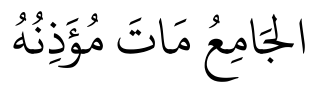

Masjid pun kehilangan muadzinnya

$$
\text { الميِّت مَنْ سَيُوَبِنِّهُ }
$$

Mayat orang yang berduka

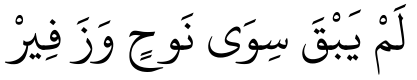

Tak tersisa kecuali ratapan dan rintihan

Pada ketujuh baris puisi tersebut masuk kedalam kecemasan (Anxitas) neurotik yang berupa fobia. Menjelaskan akibat dari wabah kolera ini tidak hanya menyerang psikis masyarakat Mesir tetapi juga membuat mereka trauma atau fobia. Yang diisyaratkat dalam baris "masjid yang kehilangan muadzinnya" sampai "penggali kubur pun meninggal dunia." Semua sungguh membuat masyarakat Mesir semakin menderita dan begitu membuat mereka tersiksa.

\section{Baris 46-48}

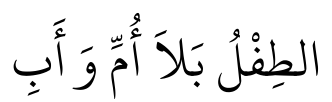

Seorang anak tanpa ibu dan bapak

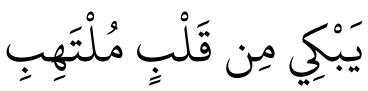

Dia menangis dari hati yang tersiksa

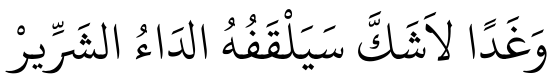

Besok pasti akan direnggut oleh penyakit yang mengerikan 
Pada ketiga baris puisi tersebut masuk kedalam kecemasan (Anxitas) moral yaitu perasaan takut yang ada dalam hati individu yang terjadi karena pertentangan hati dan sosial. Menjelaskan bahwa seorang anak tertekan karena keadaan yang terjadi di Mesir akibat wabah kolera. Selain kehilangan orang tua mereka berubah statusnya menjadi anak yatim piatu.

\section{Baris 49-52}

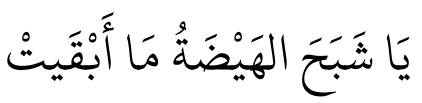

Wahai hantu yang tak menyisakan apa-apa

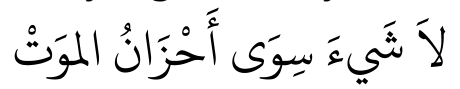

Hanya kematian yang menyedihkan<smiles>[SiH3][SiH2][SiH2][SiH2][SiH3]</smiles>

Kematian kematian kematian

Pada ketiga baris puisi tersebut masuk kedalam kecemasan (Anxitas) neurotik. Menjelaskan bahwa wabah kolera datang ke Mesir seperti hantu dan membunuh para korbannya. Pada baris puisi tersebut mengisyaratkan bahwa mati memang benar-benar sudah menjadikan masyarakat fobia saat mendengarnya.

\section{Baris 53}

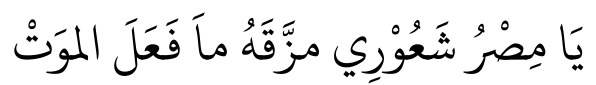

Wahai Mesir yang dikoyak kejamnya kematian

Pada baris puisi tersebut masuk kedalam kecemasan (Anxitas) objektif. Menjelaskan bahwa Mesir saat itu benar-benar sudah dikuasai oleh wabah kolera. Tidak ada obat yang bisa menyembuhkan para penderitanya selain kematian, mereka tidak bisa bersembunyi dan hanya bisa menangis serta meratapi kapan gilirannya untuk mati.

\section{SIMPULAN}

Kecemasan (Anxitas) merupakan keadaan atau situasi apapun yang mengganggu dan mengancam kenyamanan organisme. Mulai dari berbagai konflik, frustasi, dan apapun yang bisa menghambat tujuan dari seseorang (bentuk ancamannya bisa berupa fisik, psikis dan berbagai tekanan, perasaan khawatir, takut, 
dan tidak bahagia). Sedangkan dalam Puisi Al-Kulira yang terdiri dari 53 baris ini ditemukan ada 3 bentuk kecemasan (Anxitas) yaitu kecemasan (Anxitas) objektif, kecemasan (Anxitas) neurotik, dan kecemasan (Anxitas) moral, namun lebih banyak di dominasi oleh kecemasan objektif. Dari sini jelas membuktikan bahwa psikologi sangat berperan penting terhadap penciptaan karya sastra.

\section{DAFTAR PUSTAKA}

Dewi P Yeny, Andri. Juli 2007. Teori Kecemasan Berdasarkan Psikoanalisis Klasik dan Berbagai Mekanisme Pertahanan terhadap Kecemasan. Departemen Psikiatri Fakultas Kedokteran UI : Maj Kedokt Indon. Volum 57. Nomor 7.

Endraswara Suwardi. 2013. Metodologi Penelitian Sastra. Yogyakarta: CAPS (Center for Academic Publishing Service).

Fajriyah Khoiriyatul, dkk. Juni 2017. Kajian Psikologi Sastra. FIB KALTIM: volume 3, nomor 1 .

Harjito, Umaya Nazia Maharani. 2017. Penelitian Pembelajaran Sastra. Semarang: Universitas PGRI Semarang Press.

Harsanti Intaglia, dkk. 2013. Psikologi Umum 1. Universitas Gunadarma.

https://archive.alsharekh.org/Articles/6/168/372492. Rabu 3 Februari 2021. 11.40 wib.

https://www.arabworldbooks.com/e-zine/لمحات-من-سيرة-حياتي-وثقافتي. Rabu 3 Februari 2021. 11.40 wib.

Minderop Albertine. 2010. Psikologi Sastra. Jakarta: Yayasan Pustaka Obor Indonesia Anggota IKAPI DKI Jakarta.

Muslim, Fauzan \& Nurfitri. 2014. Tema Kesedihan Dalam Puisi Al-Kuuliiraa Karya Nazek Al-Malaika. FIB.

Nailarrochim Noor. 2020. Puisi Al-Kulira karya Nazik Al-Mala'ikah (Studi Analisis Semiotika Michael Riffaterre). 'Ajamiy: volume 9 no 2.

Saedi Ali. Nazik Al-Malaika. Android 2.0. apk.

Santosa Puji. 2015. Metodologi Penelitian Sastra Paradigma, Proposal, Pelaporan, Dan Penerapan. Yogyakarta: Azzagrafika.

Wiyatmi. 2011. Psikologi Sastra. Yogyakarta: Kanwa Publisher. www.adab.com. 
Yasin, Ali Nur, and Darisy Syafaah. "Struktur Kepribadian Tokoh Iryân Dalam Novel Al-Rajulu Al-Lazî Âmana Karya Najib Al-Kailani (Analisis Psikologi Sigmund Freud)." Tsaqofiya: Jurnal Pendidikan Bahasa Dan Sastra Arab 3, no. 1 (2021): 61-75. 